\title{
Tipos, personificações e conflitos entre demônios em Os Sertões
}

\author{
Pedro Lima Vasconcellos
}

FERRAZ, S., et al.,orgs. Deuses em poéticas: estudos de literatura e teologia [online]. Belém: UEPA; Campina Grande: EDUEPB, 2008. 364 p. ISBN 978-85-7879-010-3. Available from SciELO Books $<\underline{\text { http://books.scielo.org }>\text {. }}$

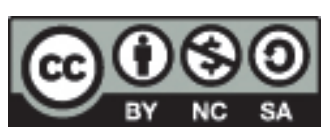

All the contents of this work, except where otherwise noted, is licensed under a Creative Commons Attribution-Non Commercial-ShareAlike 3.0 Unported.

Todo o conteúdo deste trabalho, exceto quando houver ressalva, é publicado sob a licença Creative Commons Atribuição Uso Não Comercial - Partilha nos Mesmos Termos 3.0 Não adaptada.

Todo el contenido de esta obra, excepto donde se indique lo contrario, está bajo licencia de la licencia Creative Commons Reconocimento-NoComercial-CompartirIgual 3.0 Unported. 


\section{Tipos, personificações e conflitos entre demônios em Os Sertões}

Pedro Lima Vasconcellos 


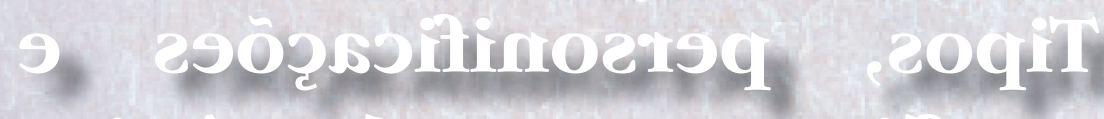
zoinoms. stung, zojilinos

\section{zeojnse zarms}

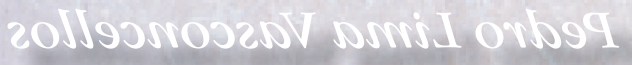


VASCONCELLOS, Pedro Lima*

A interpretação do grandioso Os sertões, de Euclides da Cunha, vem desafiando analistas e críticos desde sua publicação, em fins de 1902. A poderosa e complexa escrita do livro é um fator a dificultar sua compreensão. Mas alguns aparentes paradoxos na superfície do texto vêm complicar ainda mais a tarefa de identificar o que, no final das contas, o escritor fluminense pretendeu com a produção de sua obra máxima, que lhe valeu o ingresso na Academia Brasileira de Letras e lhe mereceu fama imediata.

Nesse ensaio delineamos uma despretensiosa proposta de compreensão dessa obra que toma a sério a abordagem que o seu autor faz da dimensão religiosa inspiradora do arraial de Belo Monte, mas conhecido como Canudos. Se, por um lado julgamos que esse aspecto tem sido pouco considerado nas apreciações que Os sertões tem suscitado, por outro consideramos que uma atenção a ele pode ser contribuir na elucidação de alguns dos dilemas que a obra continua a expor às gerações que têm enfrentado sua leitura. Ao final do processo, esperamos venha emergir aquilo que, a nosso ver, constitui-se no fulcro da obra: Antonio Vicente Mendes Maciel, o Antonio Conselheiro, líder do malfadado arraial de Belo Monte, personificação acabada de um mal cuja eliminação é tarefa inescapável e ainda longe do fim.

Palavras chaves: Os Sertões, Antonio Conselheiro, mal.

\footnotetext{
* Professor Assistente-Doutor do Departamento de Teologia e Ciências da Religião e do Programa de Estudos Pós-Graduados em Ciências da Religião da PUC-SP, e ainda docente do Centro Universitário Salesiano e da Escola Dominicana de Teologia. Mestre em Ciências da Religião: Bíblia pela UMESP e Doutor em Ciências Sociais: Antropologia pela PUC-SP com a tese Terra das promessas, Jerusalém maldita: memórias bíblicas sobre Belo Monte (Canudos). Endereço eletrônico: plvascon@uol.com.br.
} 


\section{Males destruídos, embora inocentes}

Após a exposição detalhada dos contornos de Belo Monte (sempre denominada Canudos), a "urbs monstruosa" de crescimento vertiginoso, de "população multiforme" e "polícia de bandidos", com uma igreja meio santuário, meio antro, envolvida de rezas bizarras, como bizarro eram quem as entoava, Euclides da Cunha pondera:

Eram, realmente, fragílimos aqueles pobres rebelados. Requeriam outra reação. Obrigavam-nos a outra luta. Entretanto enviamos-lhes o legislador Comblain; e esse argumento único, incisivo, supremo e moralizador - a bala. (OS, p.320 $)^{94}$

Sobre o mea culpa explícito de Euclides nesta e noutras passagens de seu livro, trataremos mais a seguir. Notemos, por ora, que Euclides não renuncia, apesar de tudo, a pensar que uma luta contra o Belo Monte de Antonio Conselheiro tenha sido necessária, embora reconheça que seu teor devesse ter sido outro. Por que, então, a luta? E que outro argumento a sustentaria, que não a bala?

Para adentrarmos ao raciocínio poderoso e complexo de Euclides é preciso recuar no tempo. Quando ele ruma para a Bahia, em meados de 1897, para cobrir os dias finais da guerra contra o arraial de Belo Monte, a serviço do jornal O Estado de São Paulo, trazia na bagagem dois artigos a respeito do assunto, ambos com o título "A nossa Vendéia". ${ }^{95}$ Neles de alguma forma sintetizava um sentimento generalizado sobre o que ocorria nos sertões da Bahia. O primeiro, saído a 14/03/1897, dias após o assombroso malogro da expedição Moreira César contra o arraial, se detém principalmente numa apresentação topográfica do sertão seco e hostil. Este explica a "inconstância e toda a rudeza" ${ }^{96}$ da gente que ali vive, sensível ao fanatismo religioso do tipo

94 Como ao longo do texto serão muitas as citações de Os sertões, optamos por fazê-las utilizando a sigla $O S$ seguida da indicação da página. Os textos são extraídos da edição preparada por Leopoldo Bernucci (Os sertões: campanha de Canudos. Ateliê / Imprensa Oficial do Estado, São Paulo, 2001).

95 Como se sabe, no arraial francês da Vendéia articulou-se expressivo foco de resistência contra os rumos da Revolução Francesa, saga imortalizada por Victor Hugo em seu Quatre-vingt treize. A chamada "guerra de Canudos" começou em fins de novembro de 1896 e se encerrou no dia 05 de outubro do ano seguinte. O arraial do Belo Monte, contra o qual a guerra foi feita, foi estabelecido por Antonio Conselheiro e sua gente em junho de 1893, como desenvolvimento de uma antiga vila de nome Canudos.

96 Euclides da Cunha. "A nossa Vendéia" (1). In: DE, p.51 (Assim abreviaremos a cita- 
manifesto na Vendéia. O segundo, surgido a 17/07 do mesmo ano, no contexto de uma crescente insatisfação pela vitória que tardava, tenta explicar as dificuldades do heróico exército brasileiro, mais uma vez recorrendo à geografia. Mas adiciona um dado: a dificultar as ações está a bravura do jagunço, "tradução justalinear quase do iluminado da Idade Média. O mesmo desprendimento pela vida e a mesma indiferença pela morte dão-lhe o mesmo heroísmo mórbido e inconsciente de hipnotizado e impulsivo". ${ }^{77}$

Neste momento, a confiança que Euclides deposita no novo regime parece irrestrita. Belo Monte é fruto de "propagandistas do império" sobre a gente ignorante e ingênua do sertão, facilmente suscetível ao fanatismo. Mas "a República sairá triunfante desta última prova" ${ }^{98}$

Mas, ao comparar o Belo Monte com a Vendéia, Euclides não se refere apenas à polarização império $\mathrm{x}$ república. Como se sabe, a resistência da gente da Vendéia à Revolução Francesa tinha motivações religiosas. O "chouan fervorosamente crente" da França se alinha ao "tabaréu fanático" do sertão: ambos exercitam "o mesmo heroísmo mórbido difundido numa agitação desordenada e impulsiva de hipnotizados". 99 O vago e depreciativo fanatismo é o caminho para Euclides abordar o universo religioso dos combatentes de Belo Monte, do qual não se afastará até Os sertões. Com isso são identificados os verdadeiros inimigos:

o que se está destruindo neste momento não é o arraial sinistro de Canudos: - é nossa apatia

ção de Diário de uma expedição [Companhia das Letras, São Paulo, 2000], volume que reúne tanto os artigos mencionados de Euclides como as reportagens e telegramas que enviou ao jornal que mandara como repórter ao sertão).

97 Euclides da Cunha. "A nossa Vendéia" (2). In: $D E$, p.58 (grifos de Euclides).

98 Euclides da Cunha. "A nossa Vendéia" (1). In: $D E$, p. 52.

99 Euclides da Cunha. "A nossa Vendéia" (1). In: $D E$, p.51 (grifos de Euclides). E se em Os sertões Euclides irá num momento negar o caráter de foco monarquista sistematicamente conferido ao arraial conselheirista, que lhe justificara a comparação com a Vendéia francesa, nem por isso a alusão ao movimento francês será abandonada, e isso por conta da semelhança que o escritor encontra no terreno das convicções religiosas, raiz do monarquismo atrasado lá e cá: "Canudos era a nossa Vendéia. O chouan e as charnecas, emparelham-se bem com o jagunço e as caatingas. O mesmo misticismo, gênese da mesma aspiração política...” (OS, p.365). Por isso, tem razão Walnice Nogueira Galvão ao afirmar que, se Euclides chegou a desfazer esta identificação entre o Belo Monte do Conselheiro e a Vendéia dos contra-revolucionários franceses, quando escreveu Os sertões "não mais acredita nela, pelo menos em parte" (Gatos de outro saco: ensaios críticos. Brasiliense, São Paulo, 1981, p.70; grifo nosso). 
enervante, a nossa indiferença mórbida pelo futuro, a nossa religiosidade indefinível difundida em superstições estranhas, a nossa compreensão estreita da pátria, mal esboçada na inconsistência de uma população espalhada em país vasto e mal conhecido; são os restos de uma sociedade velha de retardatários tendo como capital a cidade de taipa dos jagunços... (DE, p.91; grifos de Euclides)

Belo Monte, capital do retardamento brasileiro, alimentado de uma "religiosidade indefinível difundida em superstições estranhas"... Note-se, ao prosseguirmos com Euclides rumo a Belo Monte, que, à sua visão dualista da sociedade dividida em progresso e atraso, futuro e passado, avanço e retardamento, república e monarquia, junta-se outra dualidade, de novo feita de um elemento aceitável e outro repugnante, agora no campo religioso: um que em Os sertões chamaria de "o belo ideal cristão" (OS, p.302), e outro, nomeado superstição, fanatismo, de que o Belo Monte será apresentado como exemplo mais consistente. Até aqui Euclides desconhece a realidade da guerra, tem com ela alguns poucos contatos, dela ainda se avizinha, mas já sabe que deuses e demônios também estão nela atuando, aqueles de um lado e estes, obviamente, a combatê-los. Faltaria apenas certificar-se da confirmação do quadro.

Ao chegar finalmente e divisar o arraial (DE, p.174-182), em meados de setembro, Euclides não consegue conter o espanto, a começar, como de costume, com a topografia. A seguir descreve o vilarejo, caótico, mas admirável, que, apesar dos bombardeios, permanece praticamente intacto. A reportagem é impactante, ao expressar a surpresa provocada com o ainda que tardio encontro com a cidadela de que tanto já falara e ouvira falar, capaz de provocar pânico em todo o país.

No entanto, não é o momento de revisão de posições. Pelo contrário: a segunda metade da correspondência se encarregará de esboçar explicações, agora com dados colhidos in loco, para as dificuldades encontradas pelo exército no cumprimento de sua missão, especialmente no tocante ao combate de 18 de julho, um dos mais sangrentos da guerra. ${ }^{100}$

100 A derrota nesse combate exigiu do general Artur Oscar, praticamente confessando seu malogro nesta circunstância, pedir um reforço de cinco mil soldados, o que repercutiu muito mal nos ambientes do Rio e São Paulo. Uma descrição deste combate pode ser lida em Edmundo Moniz. Canudos: a guerra social. 2 ed., Elo, Rio de Janeiro, 1987, p.191-200. Como se vê, a chegada de Euclides a Belo Monte possibilita-lhe, mais uma vez, satisfazer a opinião pública, insatisfeita pela inexplicável demora na eliminação do 
É neste quadro que surgem duas referências altamente expressivas que, por remeterem diretamente a imagens bíblicas, passamos a comentar. Primeiramente o olhar sobre a cidadela aparentemente vazia, intensamente bombardeada, unanimemente execrada, mas ainda de pé. Ruínas muitas, que não impedem divisar um portentoso empreendimento. Mas, e por conta disso, já que se olha "para a aldeia enorme e não se lobriga um único habitante", pensa-se em "uma cidade bíblica fulminada pela maldição tremenda dos profetas" ( $D E$, p.178).

Parece que, por um momento, Euclides perdeu de vista as inquietações que começaram a atormentá-lo quando do seu contato com a gente sertaneja barbarizada. A contemplação atenta do jornalista por um momento deixa os detalhes topográficos e viaja a Israel, ao mundo bíblico, ao encontro de profetas vaticinadores do terror e da destruição. E ele os encontra abundantemente. Várias cidades têm seu desaparecimento anunciado; por exemplo, a cidade de Nínive, a capital do império assírio, que Jonas (no livro profético de mesmo nome) declara prestes a ruir, devido às atrocidades ali planejadas. A surpresa é que a ameaça não se cumpre.

No entanto, a cidade que na Bíblia tem sua destruição muitas vezes anunciada é Jerusalém, por conta de sua política e religião abomináveis, e é especialmente nela que Euclides está a pensar. É ela que merece as condenações de Miquéias, Isaías ou Jeremias. Séculos depois, é Jesus de Nazaré que, segundo os evangelhos vaticina contra ela, apontando sua destruição. Para Euclides, a Jerusalém sertaneja tem sua iminente destruição selada com o beneplácito divino. Inclusive para que sejam vingados aqueles que no cumprimento do sacro dever foram hostilizados, feridos e mortos: verdadeiros mártires. ${ }^{101} \mathrm{~A}$ cidade santa bíblica é transposta para as margens do Vaza-barris, feita agora a capital do retardamento; precisa então ser destroçada pela ação das tropas civilizadas.

Agora a segunda referência. Se Belo Monte é a "aldeia sinistra", se o exército não faz outra coisa que realizar a implacável vontade divina, o que são os rebeldes sertanejos, habitantes do horror? Euclides não escapa à conclusão: o exército demora em alcançar a tão sonhada vitória porque seus inimigos são sobrenaturais, terrivelmente sobrenaturais. Eles, que parecem não vir de nenhum lugar, seriam, ao olhar da fantasia, "uma legião invisível e intangível de demônios..." (DE, p.178)

"incompreensível e bárbaro inimigo" (DE, p.199).

101 Para a qualificação dos soldados como mártires veja $D E$, p.69. 
Em Belo Monte os demônios estão aos montes, formam uma "legião". Se não a consideramos casual, esta metáfora, a da "legião de demônios", também tem sua matriz no universo bíblico. Nela, Euclides atribui aos jagunços belomontenses uma característica que ao mesmo tempo nos remete para duas esferas, ao menos. Não terá passado despercebido ao jornalista que o termo aponta para o mundo militar, e é neste contexto que aparece aqui. No entanto, o que mais surpreende é o fato de seus componentes serem demônios. E aí, mais do que uma coincidência, isto parece remeter para uma passagem do evangelho (Marcos 5,1-20):

E ao sair Jesus da barca, veio logo a ele dos sepulcros um homem possesso do espírito imundo [...] E dando um grande grito, disse: Que tens tu comigo, Jesus, Filho de Deus altíssimo? [...] E [Jesus] perguntou-lhe: Que nome é o teu? Ao que ele respondeu: Legião é o meu nome, porque somos muitos (Marcos 5:2-10).

É notável que Euclides tenha percebido o alcance político-militar desta passagem bíblica: o demônio-legião é imagem da ocupação e violência romanas sobre Israel. ${ }^{102}$ Mas cabe notar a direção impressa à metáfora; aqui não é demoníaco quem vem de fora, mas quem reage ao invasor. Legiões não são as tropas republicanas, mas os rudes sertanejos. A violência é provocada pelos jagunços; isso fica patente no fato de Euclides se referir à "legião de demônios" quando fala do uso de armas que estes fazem. ${ }^{103} \mathrm{O}$ desconhecimento da topografia e das estratégias do inimigo, que o tornam operante e resistente, converte-o em um coletivo diabólico. Não se pode, portanto, ignorar o caráter altamente estigmatizador da expressão utilizada: a desumanização do outro chega aqui a um ponto alto.

É difícil imaginar como isso coaduna com o que Euclides escrevera ainda antes de chegar ao terreno do combate:

102 Essa é uma percepção que apenas recentemente a pesquisa exegética buscou desenvolver (Ched Myers. O evangelbo de são Marcos. Paulus, São Paulo, 1992, p.237-241; John D. Crossan. OJesus histórico. A vida de um camponês judeu do Mediterrâneo. 2 ed., Imago, Rio de Janeiro, 1994, p.350-355).

103 Aliás, esta não é a primeira vez que Euclides aproxima os sertanejos dos demônios: na reportagem de 20 de agosto, ainda na capital da Bahia, menciona a "perversidade satânica" dos jagunços ( $D E$, p.115). No entanto, aqui é o substantivo que caracteriza os sertanejos rebeldes. Não merecerá imagem semelhante o exército em qualquer das descrições de ataques por este realizados. 
penso que a nossa vitória, amanhã, não deve ter exclusivamente um caráter destruidor. Depois da nossa vitória, inevitável e próxima, resta-nos o dever de incorporar à civilização estes rudes patrícios que - digamos com segurança - constituem o cerne de nossa nacionalidade $\left(D E\right.$, p.140).$^{104}$

Os inimigos não aparecem aí como jagunços, mas como patrícios, embora rudes; não demônios, embora transviados, indiscutivelmente, pelo Conselheiro. ${ }^{105}$ Assim, se para Euclides os sertanejos "constituem o cerne de nossa nacionalidade", só o são "descontadas as superstições". ${ }^{106}$ No fim das contas, essas últimas deram a justificativa última para a ação bárbaro-civilizatória, se é possível falar assim, que Euclides esperava fosse seguida do envio do mestre-escola para civilizar os sertanejos ( $D E$, p.92).

Já em Os sertões, que Euclides começa a escrever meses após sua volta da Bahia, ao ser nomeado para acompanhar a reconstrução de uma ponte em São José do Rio Pardo, interior paulista, o tom se modifica sensivelmente. Como vimos, as últimas reportagens deixavam antever uma significativa revisão de posições. Aqueles que até então eram tidos como demônios são vistos agora como compatriotas, embora desencaminhados. E um poema, criado em Salvador dias depois da volta do campo de guerra, e de ter misteriosamente silenciado, em suas reportagens, sobre a brutalidade dos últimos combates, dá conta do que lhe passa na cabeça: "Quem volta da região assustadora / De onde eu venho, revendo, inda na mente / Muitas cenas do drama comovente $\angle$ Da Guerra despiedada e aterradora [...]"107

104 Mas no fim da estadia em Belo Monte, parece que Euclides se mostra mais sensível ao drama do outro, praticamente eliminado. E praticamente pede licença aos leitores da capital paulista para expressar sua admiração pela bravura dos que anteriormente caracterizara como portadores de uma "perversidade satânica". Parece até antecipar aquela decepção com o massacre que vê e com as atitudes do exército republicano que se manifestará mais tarde em Os sertões, embora sem dúvida de que é a República que deve triunfar, e de que não há espaço para o que Belo Monte representa: "Sejamos justos - há alguma coisa de grande e solene nesta coragem estóica e incoercível, no heroísmo soberano e forte dos nossos rudes patrícios transviados e cada vez mais acredito que a mais bela vitória, a conquista real consistirá no incorporá-los, amanhã, em breve, definitivamente, à nossa existência política" (DE, p.208).

105 Também na reportagem de $1^{\circ}$ de setembro ( $D E$, p.140) os sertanejos rebeldes são chamados "rudes patrícios".

106 Nicolau Sevcenko. Literatura como missão. Tensões sociais e criação cultural na Primeira República. 4 ed., Brasiliense, São Paulo, 1999, p.145.

107 Esta é a primeira estrofe do soneto "Página vazia", datado de 14/10/1897 (Cadernos 


\section{Males destruidores, embora...}

Mas é na escrita de seu livro maior que Euclides poderá dar vazão às contradições que vem carregando dentro de si desde quando testemunhou o cruel massacre sem poder denunciá-lo. Quanto ao alcance desta revisão, teremos oportunidade de avaliá-lo. Por ora, importa notar que, para a composição do argumento euclidiano, o recurso ao universo religioso e teológico será inevitável. Até porque Euclides não conseguirá compreender o sentido e o alcance da experiência religiosa vivida no arraial belomontense. Nesse aspecto não se afastará das críticas anteriores. Talvez seja maior a pretensão do ataque aos rumos da República, manifestos cabalmente na empreitada militar, que o anseio por defender a gente sertaneja. ${ }^{108}$ Assim, no livro convivem, em permanente tensão, um "saber, considerado natural e científico, e um julgar, de natureza ética mais ampla": o primeiro "quer explicar a luta contra Canudos"; o segundo "a denuncia". ${ }^{109}$

Consideremos uma imagem poderosa do fim da guerra, o arraial praticamente destruído. Incêndios aqui e ali, de uma fumaça interminável, que

progrediam constrangidos, ao arrepio do sopro do nordeste, esgarçando-lhes a fumarada amarelenta, ou girando-a em rebojos largos em que fulguravam e se diluíam listrões fugazes de labaredas... Nesses intervalos desaparecia o arraial. Desaparecia inteiramente a casaria. Diante dos espectadores estendia-se, lisa e pardacenta, a imprimadura, sem relevos, do fumo. Recortava-a, rubro e sem brilhos, - uma chapada circular em brasa - um Sol bruxuleante, de eclipse. Rompia-a, porém, de súbito, uma lufada rija. Pelo rasgão enorme, de alto a baixo aberto, divisava-se uma nesga do arraial - bandos estonteados de mulheres e crianças correndo para o sul, em tumulto, indistintos entre as folhagens secas da latada (OS, p.714-715).

de Literatura Brasileira. São Paulo, 2002. n.13/14, p.160-161).

108 Nas notas à segunda edição de Os sertões, Euclides precisará: "Não tive o intuito de defender os sertanejos porque este livro não é um livro de defesa; é, infelizmente, de ataque" (OS, p.784).

109 Alfredo Bosi. Literatura e resistência. Companhia das Letras, São Paulo, 2002, p.213. Para a contextualização dessa "esquizofrenia" da obra de Euclides, pode-se ler Valentim A. Facioli. Euclides da Cunha: a gênese da forma. Tese de doutoramento, Universidade de São Paulo, 1990, p.97-114. 
Justo nesse dia, pouco depois da morte do Conselheiro, quando Euclides pôde dizer que "a insurreição estava morta" (OS, p.717), porque o cerco do Exército ao arraial finalmente se consumara, a descrição da tragédia assume cores densas e evoca imagens dantescas, amplamente conhecidas:

A cena é sugestiva por causa de seu pano de fundo bíblico, da evocação do que ocorreu na hora da morte de Jesus, assim narrada pelo evangelista Lucas $(23,44-45)$ : "E era já quase a hora sexta, e houve trevas em toda a terra até a hora nona, escurecendo-se o sol; e rasgou-se ao meio o véu do templo". Na versão do evangelista Mateus (27,5052): "Jesus, clamando outra vez com grande voz, rendeu o espírito. E eis que o véu do templo se rasgou em dois, de alto a baixo; e tremeu a terra, e fenderam-se as pedras. E abriram-se os sepulcros, e muitos corpos de santos, que dormiam, foram ressuscitados...". O paralelismo é patente. A batalha ocorre em volta e em cima dos templos de Canudos, dois dias após a morte do "bom Jesus", comunicada ao leitor duas páginas antes, de modo que se pode dizer aproximadamente que à sua morte seguiu-se o eclipse. A vinculação cronológica entre a morte do Conselheiro e o rasgamento do véu sobre a "Jerusalém de taipa" portanto é muito estreita; chegam a ser quase simultâneos na mente do narrador, naquele dia da condenação à morte de Canudos, sem que ninguém do exército, durante a batalha, soubesse ao certo da morte do Conselheiro dois dias antes. ${ }^{110}$

Mas o recurso a essas imagens e "cenas antiqüíssimas do imaginário ocidental" não se deve apenas ao "efeito estético e retórico", mesmo que para "impressionar, entristecer, indignar"111, pretendido pelo livro. Na verdade, a menção ao relato da morte de Jesus é sintomática, por revelar o posicionamento de Euclides e sua opção ao pretender escrever um "livro vingador". Não é pouco associar o desaparecimento do Conselheiro e desespero final da gente sertaneja à paixão de Jesus.

110 Berthold Zilly. "A guerra como painel e espetáculo. A história encenada em Os sertões". In: História, Ciências, Saúde. Rio de Janeiro, 1998. v.5 (suplemento), p.29.

111 Expressões de Berthold Zilly ("A guerra como painel e espetáculo...”, p.29). Na mesma página ele afirma: "Quando [Euclides] evoca o que acontece com a cortina sobre o teatro da guerra, com essa 'imprimadura, sem relevos, do fumo' sentimos um calafrio que sobe das profundezas de nossa cultura e emotividade..." 
E justamente o recurso aos fenômenos cataclísmicos radicaliza a dimensão de tragédia, tanto nos relatos ancestrais como no que neles se inspira. ${ }^{112}$ Assim, a vinculação do destino trágico dos sertanejos ao do Jesus crucificado não deve ser avaliada apenas em seu efeito literário. Ela mostra que seu autor fez um longo caminho, que o levou do quase escárnio inicial a uma explícita "simpatia pelos nossos extraordinários patrícios sertanejos"113, capaz de causar estranheza em alguns de seus primeiros leitores mais cuidadosos. ${ }^{114} \mathrm{E}$ se antes o Exército aparecia como agente dos desígnios divinos, o que dizer dele agora, algoz dos novos crucificados?

Com efeito, não escapou a alguns dos mais atentos leitores de $O s$ sertões que este reservava ao Exército brasileiro e, por extensão, à República que o enviou ao Belo Monte de Antonio Conselheiro, palavras altamente críticas. Os artigos do militar José Maria Moreira Guimarães, publicados em fevereiro e março de 1903, externam esse incômodo, e a estranheza frente às palavras desabonadoras frente ao Exército e sua ação nos sertões baianos. ${ }^{115}$ No entanto, não seria muito difícil perceber essa faceta da escrita de Euclides; na verdade ela está indicada na abertura da obra:

Aquela campanha lembra um refluxo para o passado.

E foi, na significação integral da palavra, um cri-

112 Cabe notar que a alusão a tais fenômenos, como as trevas surgidas em pleno dia e o rasgo do véu do templo, não é feita no evangelho segundo João, o que acentua ainda mais seu caráter retórico. O contraponto que melhor evidencia a densidade da narrativa oferece-nos o próprio Euclides, na reportagem relativa ao mesmo dia 24 de setembro, quando fala de alguns prisioneiros (entre eles "uma velha com a feição típica de raposa assustada") e combates; a abertura sumaria o sentido do que descreverá: "Completo ontem o cerco de Canudos, a luta correrá vertiginosamente, agora. Os sucessos de hoje o indicam" ( $D E$, p.182). Nem por um momento terá recordado qualquer sexta-feira santa... Sucessos do Exército, eis o que interessava mostrar, ou então a insanidade da gente belomontense.

113 Carta a Araripe Junior, de 30/03/1903. In: Walnice Nogueira Galvão e Oswaldo Gallotti (org.) Correspondência de Euclides da Cunha. Edusp, São Paulo, 1997, p.159.

$114 \mathrm{O}$ crítico literário Araripe Júnior, um dos primeiros a se manifestar a respeito de $O s$ sertões, manifesta, de forma sutil, seu desacordo com Euclides: este "imputou talvez maior importância do que devia a esse despeitado da vida [Antonio Conselheiro]" ("Os sertões [Campanha de Canudos por Euclides da Cunha]”. In: José Leonardo do Nascimento e Valentim Facioli [org.]Juízos críticos: Os sertões e os olhares de sua época. Nankim / Unesp, São Paulo, 2003, p.65).

115 Veja textos em José Leonardo do Nascimento e Valentim Facioli (org.) Juízos críticos..., p. 87-101. 
me.

Denunciemo-lo (OS, p.67).

Na mesma oportunidade Euclides afirma que os emissários da República enviados a Belo Monte, soldados, jornalistas, todos "tivemos na ação um papel singular de mercenários inconscientes" (OS, p.66) Essa última expressão também saltou à vista de alguns dos leitores mais atentos de Os sertões; segundo o comentário de Euclides para a segunda edição: "estranhou-se a expressão. Mas devo mantê-la: mantenho-a" (OS, p.783).

Efetivamente, Euclides esperava outra coisa dos agentes máximos do regime em que tudo apostou. E soube expressar sua decepção também de maneira sutil e poderosa. Num momento perdido entre os avanços da quarta expedição, uma página nos remete para o Oriente Médio, a "uma paisagem bíblica" (OS, p.592). ${ }^{116}$ Uma "tapera babilônica" na qual se enfurnavam quem sabe vinte mil pessoas em cinco ou seis mil casebres, com seu entorno evocava a longínqua e desconhecida Iduméia (também chamada Edom). Região ao sul de Judá, habitada por descendentes de Esaú, irmão gêmeo de Jacó, o ancestral de Israel. Ambos os povos desenvolveram uma trajetória acidentada, de conflitos e traições mútuas. Daí que a Bíblia lhe reserve palavras desabonadoras e anúncios de destruição, o que permitiu a Euclides falar dela como "esterilizada para todo o sempre pelo malsinar fatídico dos profetas" (OS, p.592). ${ }^{117}$

Mas se o registro fosse apenas esse, não faria sentido aludir à desconhecida Iduméia. Na verdade, este aspecto não é o único. Os idumeus não são apenas os inimigos de Israel. São, antes de tudo, seus irmãos. Daí que noutra passagem, quando Israel necessitava passar pelo território edomita para chegar a sua terra prometida, diante da recusa, Moisés tenha optado por contorná-lo a fazer guerra ao povo do mesmo sangue (Números 20,14-21). A conclusão é clara: "Ao evocar a terra da Iduméia, Euclides invoca, também, nas entrelinhas, a tarefa mosaica que, afinal, é a dele [...] como verdadeiro porta-voz da civilização diante da barbárie". ${ }^{118}$ E que o Exército deixara de realizar.

116 As considerações a seguir devo-as a Flávio Aguiar, que gentilmente me enviou cópia impressa de seu ensaio "A volta da serpente. Um estudo sobre Os sertões, de Euclides da Cunha".

117 As citações bíblicas em que as invectivas contra Edom aparecem de forma mais categórica são o S1 137 e a profecia de Abdias, bem como Is 34. Nestes casos o contexto é o da colaboração edomita para a destruição de Jerusalém pelos babilônios.

118 Flávio Aguiar. "A volta da serpente..." 
Da mesma maneira é eloqüente a evocação de uma passagem bíblica em que, apesar de evidentes conflitos, dois povos irmãos não os resolvem pela guerra. Ou melhor, um deles, divinamente conduzido, não violenta o supostamente inferior e refratário. Pode-se supor que Euclides esperaria da República uma ação civilizatória como a realizada por Moisés. Sua decepção se expressa também ao perceber que, pelo contrário, o resultado da presença da civilização no sertão foi desastroso, convertendo-o num imenso Gólgota.

\section{O mal personificado que demandava ser antes des- truído}

A essa altura, quem se aventura pelas páginas de Os sertões e nos acompanha no percurso que temos proposto, certamente se fará a pergunta: se a legião que combate o exército brasileiro é feita de demônios, e por isso precisa ser debelada (até porque seu desaparecimento é inevitável); mas, se, de outro lado, os que as combatem são como mercenários inconscientes, merecedores, junto com o regime que os enviou ao sertão, da denúncia mais consistente, onde se encontra a saída para o impasse a que a obra conduz? No pensar de Euclides, a despeito de toda sua confessada simpatia pelos "nossos rudes patrícios sertanejos", uma luta endereçada a eles era necessária. A República com seus agentes tinha de fazê-la, mas errou na escolha das armas: a bala em vez do mestre-escola? Mas, no fim das contas, por que a luta era necessária? Quem era o inimigo a ser combatido implacavelmente?

A sugestão que aqui propomos deriva da convicção segundo a qual o juízo sobre o componente religioso estruturador de Belo Monte é decisivo para a percepção euclidiana do vilarejo e de seu sentido. Assim sendo, devemos deslocar-nos ao capítulo 4 da parte II de Os sertões, ao encontro do desenho que Euclides traça do perfil de Antonio Vicente Mendes Maciel, o Antonio Conselheiro.

Mas antes, é preciso, mais uma vez, fazer um recuo ao tempo da guerra e das reportagens. Já vimos nelas Euclides afirmar que o que se estava destruindo em Belo Monte era a religiosidade expressa em superstições, que tinha como capital brasileira exatamente o Belo Monte. No entanto, já ficava claro ao jornalista que o líder de Belo Monte, Antonio Vicente Mendes Maciel, "espécie bizarra de grande homem pelo avesso, tem o grande valor de sintetizar admiravelmente todos os elementos negativos, todos os agentes de redução de nosso povo" (DE, 
p.89). As linhas seguintes mostrarão Euclides tratando de "demitizar" a interpretação teológica que o Conselheiro faria de si mesmo. E mesmo quando algumas dúvidas já se tiverem instalado no interior das certezas do escritor, sua percepção do Conselheiro não se modificará: trata-se de um "evangelizador fatal e sinistro que os arrastou [os sertanejos] a uma desgraça incalculável" (DE, p.187).

Em Os sertões a avaliação que Euclides faz do Conselheiro apenas se agrava; com seu "sistema religioso incongruente e vago" (OS, p.275), ele concentra todos os males do seu povo. Nele se expressam o atraso racial e os absurdos religiosos sincréticas. Este desenho do Conselheiro indica a inviabilidade do que Belo Monte representava. Eis o porquê de encontrarmos, a todo momento, alusões ao "falso apóstolo" e a suas profecias, em que se alternam ironia e crítica. Ele não tem dúvidas: nas prédicas do "retrógrado do sertão" o que se nota é o ressurgimento total das "aberrações", que se julgariam extintas, dos "adoidados chefes de seita dos primeiros séculos" (OS, p.275).

A menção aos hereges dos inícios do cristianismo não é meramente ilustrativa, mas se articula ao fato de o Conselheiro ser tomado por "um bufão arrebatado numa visão do Apocalipse" (OS, p.274), e nos conduz ao foco da elaboração especulativa e literária de Euclides da Cunha: Antonio Conselheiro como "um documento raro de atavismo" (OS, p.253), seja pela nota étnica, seja principalmente pelo fato de condensar, "em seu misticismo feroz e extravagante", "todas as crenças ingênuas, do fetichismo bárbaro às aberrações católicas, todas as tendências impulsivas das raças inferiores, livremente exercitadas na indisciplina da vida sertaneja" (OS, p.252).

A referência ao livro do Apocalipse remete o líder de Belo Monte a um mundo particular, que será decisivo na interpretação euclidiana a seu respeito: o da profecia milenarista. ${ }^{119}$ É bem verdade que o perfil

119 Quanto ao milenarismo (ou quiliasmo), achamos conveniente precisar o que entendemos pelo termo, dados os equívocos que se costuma cometer a esse respeito. O conceito vem de uma passagem do livro do Apocalipse $(20,1-$ 6), e diz respeito à "crença num reino terrestre vindouro de Cristo e de seus eleitos - reino este que deve durar mil anos, entendidos seja literalmente, seja simbolicamente"; trata-se de uma "espera de um reino deste mundo, reino que seria uma espécie de paraíso terrestre reencontrado" (Jean Delumeau. Mil anos de felicidade: uma história do paraíso. Companhia das Letras, São Paulo, 1997, p.17-18; veja Pedro Lima Vasconcellos. "A vitória da vida: milênio e reinado em Apocalipse 20,1-10". In: Revista de Interpretação Bíblica Latino-Americana. Petrópolis, 1999. n. 34, p.79-92). Esperança essa alimentada por "movimentos 
do Conselheiro que daí surgirá não encontra qualquer apoio na documentação, mesmo aquela recolhida por Euclides em sua Caderneta de campo, muito menos nos registros de outros jornalistas, militares e religiosos que conheceram o arraial e deixaram escritas suas impressões. Mas o que importa aqui é notar, e tirar as conseqüências dessa sua "invenção", até porque ela fez história. ${ }^{120}$ Ela se constrói a partir de algumas "profecias" encontradas em Belo Monte, que Euclides equivocadamente atribuiu ao Conselheiro, além de tê-las entendido em termos milenaristas. ${ }^{121}$ Vista dessa forma, a vila conselheirista não seria sociais que procuram uma mudança radical e maciça de acordo com um plano divino predeterminado. Seus membros rejeitam, em geral, a ordem social vigente e dela se afastam" (Robert Levine. O sertão prometido: o massacre de Canudos. Edusp, São Paulo, 1995, p.29), pois "agora mesmo o mundo estava se aproximando, por meio de incessantes conflitos, de um estado sem nenhum conflito. Chegaria um momento em que, em uma prodigiosa batalha final, o deus supremo e seus aliados derrotariam as forças do caos e seus aliados humanos, aniquilando-os de uma vez por todas. A partir de então, a ordem divinamente estabelecida estaria presente de maneira absoluta; as necessidades e as misérias físicas seriam desconhecidas $[\ldots]$ a ordem do mundo jamais voltaria a ser perturbada ou ameaçada" (Norman Cohn. Caos, cosmo e o mundo que virá: a origem das crenças no Apocalipse. Companhia das Letras, São Paulo, 1996, p.296). A ação divina transformará o cosmos e o recriará de forma a se superarem os dramas presentes, o que modifica a postura diante da opressiva hora atual. O tempo novo integra um plano divino previamente estabelecido e de cuja revelação e conhecimento vivem os milenaristas, pois representará a salvação deles e a destruição dos pecadores, os responsáveis pelo atual estado de coisas (Vittorio Lanternari. "Milênio". In: Enciclopédia Einaudi. Imprensa Nacional - Casa da Moeda, 1994, s/1, v.30 (Religião - Rito), p. 303-324).

120 Assistimos, portanto, a uma situação curiosa: se Thompson tem razão ao afirmar que, "embora historiadores e sociólogos tenham recentemente se dedicado com maior atenção aos movimentos e fantasias milenaristas, o seu significado se mantém parcialmente obscurecido pela tendência em discuti-los em termos de desajuste e "paranóia" (Edward P. Thompson. A formação da classe operária inglesa. 3 ed., Paz e Terra, Rio de Janeiro, 1997, v.1 [A árvore da liberdade], p.50), no caso da análise euclidiana foi necessário inventar um Belo Monte milenarista para que seus habitantes, particularmente seu líder, pudessem ser considerados sob prismas semelhantes àqueles mencionados pelo historiador inglês.

121 Sobre as "profecias" populares de Belo Monte, onde se encontra a famosa expressão "o sertão virará praia, e a praia virará sertão", ver textos em Euclides da Cunha. Caderneta de campo. Cultrix / Instituto Nacional do Livro. São Paulo, 1975, p.74-75. Para uma análise desta e outras expressões do povo do Belo Monte, pode-se ler, em nossa tese já mencionada, as p.188-209. Já as prédicas de Antonio Conselheiro, que Euclides não conheceu, têm perfil muito distinto, e é lamentável que o desenho euclidiano a esse respeito ainda se mantenha, deixando a produção literária do Conselheiro no ostracismo. 
outra coisa que uma comunidade de pessoas ansiando pela vinda do milênio, de uma nova era, como tantas outras "pré-Jerusaléns, salas de espera espirituais onde se aguardava a entrada triunfal 'na mais fértil das terras', no reino miraculoso cheio de bênçãos para o corpo e para a alma". ${ }^{122} \mathrm{O}$ que ali se vivia apenas prefigurava o que estava para se dar, do qual apenas os eleitos, os habitantes do arraial, seriam os beneficiados. Daí a separação do mundo, a recusa em observar as leis estabelecidas, a revolta contra a ordem política estabelecida. E é isso mesmo que Euclides vê em Belo Monte. Os habitantes de Belo Monte "nada queriam desta vida", vivendo que estavam "sob a preocupação doentia da outra vida" (OS, p.299), embalados no delírio religioso que, a todo momento, seu líder alimentava em inflamadas pregações e com o testemunho de sua vida penitente. O diagnóstico é inevitável: o Conselheiro é um herege. ${ }^{123}$

É esse percurso tortuoso que permite (ou melhor, exige) a Euclides associar o Conselheiro a figuras praticamente desconhecidas do cristianismo do século II, mormente Montano da Frígia. E aqui um autor lhe será decisivo: Ernst Renan (1823-1892), historiador francês. ${ }^{124}$

Dos dois manuscritos que levam o nome dele, um foi publicado por Ataliba Nogueira (António Conselbeiro e Canudos: revisão histórica. 3 ed., Atlas, São Paulo, 1997), e seu teor foi submetido a análise exemplar por Alexandre Otten ("Só Deus é grande": a mensagem religiosa de Antonio Conselheiro. Loyola, São Paulo, 1990). O outro manuscrito permanece inédito, e estamos envidando esforços tendo em vista sua publicação. Em nossa tese encontram-se algumas páginas (209-233) consagradas ao pensamento do líder do Belo Monte.

122 Robert Levine. O sertão prometido..., p. 331-332 (a expressão citada é de Norman Cohn).

123 Não entramos aqui a considerar um aspecto que nos parece muito interessante: como explicar expressões, estranhas na pena de um agnóstico, como aquela segundo a qual em Belo Monte se vislumbrava o caso de uma "seita esdrúxula - caso de simbiose moral em que o belo ideal cristão surgia monstruoso dentre aberrações fetichistas" (OS, p.302; grifo nosso). Como poderia o escritor, de outra forma, afirmar que o Conselheiro "abeirara-se apenas do catolicismo mal compreendido" ( $O S$, p.279) A que atribuir a qualificação dada à cerimônia do "beija das imagens" de "transmutação do cristianismo incompreendido" (OS, p.314)? Não se pode deixar de assinalar o acordo básico aqui notado entre o positivista Euclides e o receituário doutrinal do catolicismo ortodoxo e mesmo romanizado!

124 A Histoire des origines du christianisme, obra monumental de Ernst Renan (18231892) surgida entre 1863 e 1882, foi assumida por Euclides com particular acento no aspecto seu racial e evolucionista (Luiz Costa Lima. Terra ignota: a construção de Os sertões. Civilização Brasileira, Rio de Janeiro, 1997, p.108-124; veja também José Leonardo do Nascimento. "De Marc-Aurèle de Ernest Renan a Os sertóes de Euclides da 
Com efeito, quando Euclides passa a apresentar Antonio Maciel, na parte IV de "O homem", logo somos remetidos "aos primeiros dias da Igreja, quando o gnosticismo universal se erigia como transição obrigatória entre o paganismo e o cristianismo" (OS, p.254). Esse deslocamento até um momento longínquo da história se justifica: "um antropologista encontrá-lo-ia [o Conselheiro] normal, marcando logicamente certo nível da mentalidade humana, recuando no tempo, fixando uma fase remota da evolução" (OS, p.254). É pela perspectiva evolucionista, que, aliás, marca todo o livro, que tal recuo se dá.

Mas não é só. Euclides cita, um a um, movimentos surgidos no seio do cristianismo do século II $\left(O S\right.$, p.255). ${ }^{125}$ A presença de tal lista seria despropositada não fosse a síntese final, que dissipa qualquer dúvida: "relendo as páginas memoráveis em que Renan faz ressurgir, pelo galvanismo do seu belo estilo, os adoidados chefes de seita dos primeiros séculos, nota-se [em Antonio Conselheiro] a revivescência integral de suas aberrações extintas" (OS, p.275). O atavismo do beato de Belo Monte fica evidente quando se consideram a ação e os ensinamentos desses desconhecidos, mas aloucados líderes cristãos.

Contudo o montanismo, o primeiro grupo citado por Euclides, não é apenas um exemplo a mais de insânia. $O$ autor descobre nele características específicas que tornam a aproximação com o movimento liderado pelo Conselheiro mais que justificável: necessária mesmo. Para Renan, o montanismo, termo derivado do nome de um dos seus líderes, Montano, caracteriza "a última recrudescência do milenarismo

Cunha: milenarismo e atraso histórico". In: Interpretações sobre o movimento sertanejo de Canudos. Faculdades Salesianas, Lorena, 1997, p.13-18). O volume Marc-Aurèle et la fin du monde antique, o último da série (que abreviaremos, nas várias citações a seguir, como MA [fazendo uso de sua 26 ed., Paris, 1929]), será fundamental para a elaboração euclidiana. Com efeito, a leitura de Renan forma, com as teorias da escola antropológica italiana e da psicologia das multidões, o arcabouço teórico da análise sobre a religiosidade do Conselheiro e de sua gente que lemos em Os sertões (Alexandre Otten. "Só Deus é grande”..., p.51).

125 Além do montanismo, sobre o qual haveremos de nos alongar, Euclides cita os "adamitas infames", que, segundo Renan, "pretendiam renovar os dias do paraíso terrestre por meio de práticas muito afastadas da inocência primitiva" (MA, p.125); os "ofiólatras", "pagãos adoradores da serpente, a quem conveio um dia chamar-se cristãos" (MA, p.132); os "maniqueus", indefinidos entre o ideal cristão e o budista (MA, p.136), os "discípulos de Marcos", um gnóstico que propunha "fórmulas sobre a tétrade" e "inventou sacramentos particulares" (MA, p.127) e os "encratitas abstinentes", que repudiavam o casamento, e por conseqüência as relações sexuais, o vinho e a carne, e se serviam apenas de água nos rituais (MA, p.166-167). 
e do profetismo" (MA, p.207). Efetivamente ele se apresenta como uma releitura peculiar do Apocalipse, e foi motivado pela demora da vinda de Cristo no grande dia final e pelo relaxamento que a Igreja passou a viver em função desse atraso:

cada vez era menor o contraste entre a Igreja e o mundo. Era inevitável que os rigoristas julgassem que se estava caindo no atoleiro da mais perigosa mundanidade e que surgisse um grupo de pietistas para combater o tédio geral, continuar os dons sobrenaturais da Igreja apostólica, e preparar a humanidade, por um redobramento de austeridades, para as provações dos últimos dias (MA, p.207-208).

Esse seria o lugar ocupado, em algum momento do reinado de Marco Aurélio, imperador romano (161-180), pelo montanismo:

Espíritos simples e exaltados imaginavam ser chamados a renovar os prodígios da inspiração individual, fora das cadeias já pesadas da Igreja e do episcopado. Uma doutrina há muito tempo espalhada na Ásia Menor, a de um Paráclito que deveria vir completar a obra de Jesus, ou melhor, retomar o ensinamento de Jesus, restabelecê-lo em sua verdade, purificá-lo das adulterações que os apóstolos e os bispos nela haviam introduzido, tal doutrina, digo eu, abria a porta a todas as inovações (MA, p.210).

A forma específica a essas novidades foi dada por um tal Montano, da vila de Ardabav, na Mísia, nos confins da Frígia (região interiorana do que hoje é a Turquia): "sem dúvida a imitação dos profetas judeus e dos que a lei nova havia produzido, no começo da idade apostólica, foi o elemento principal deste renascimento do profetismo" (MA, p.211), à margem das decisões episcopais: "era um profetismo totalmente popular que surgia sem a permissão do clero, e queria governar a Igreja fora da hierarquia" ( $M A$, p.213). Desenvolvido também por Priscila e Maximila, o movimento teve grande repercussão, conquistando para suas fileiras o célebre apologista Tertuliano. $O$ rigorismo exigido de seus membros, a ânsia em recuperar o ardor dos inícios cristãos e a exortação insistente ao martírio fizeram dele uma proclamação de enorme apelo no fim do século II e início do III.

Euclides não tem dúvidas quanto a identificar no Conselheiro 
um novo Montano. O líder de Belo Monte "é um dissidente do molde exato de Themison. Insurge-se contra a Igreja romana, e vibra-lhe objurgatórias, estadeando o mesmo argumento que aquele: ela perdeu a sua glória e obedece a Satanás" (OS, p.275). Com efeito, de acordo com Renan, este personagem obscuro, mas certamente um dos líderes da seita frígia, "declarava que a Igreja católica tinha perdido toda a sua glória e obedecia a Satanás" (MA, p.222). Cá e lá as reprimendas ao "demônio dos cabelos": se nos escritos montanistas, garante-nos Renan, aparecem constantemente "proibições do luxo feminino e, sobretudo, contra o artifício dos penteados" (MA, 243-244), o Conselheiro punia "as vaidosas com dilaceradores pentes de espinho" (OS, p.276). Que a beleza fosse "a face sedutora de Satã" Renan já dizia ser convicção montanista (OS, p.276; MA, p.553). Na verdade, o ascetismo supostamente vivido em Belo Monte denunciava, para o escritor, a recriação do montanismo em terras sertanejas: "que os fiéis abandonassem todos os haveres, tudo quanto os maculasse com um leve traço da vaidade" (OS, p.276).

Mais adiante Euclides deixa ainda mais claro o vínculo entre Montano e o Conselheiro; com efeito, o frígio não é tanto um indivíduo, mas um paradigma:

Ademais esse voltar-se à idade de ouro dos apóstolos e sibilistas, revivendo vetustas ilusões, não é uma novidade. É o permanente refluxo do cristianismo para seu berço judaico. Montano reproduz-se em toda a história, mais ou menos alterado consoante o caráter dos povos, mas delatando, na mesma rebeldia contra a hierarquia eclesiástica, na mesma exploração do sobrenatural, e no mesmo ansiar pelos céus, a feição primitivamente sonhadora da velha religião, antes que a deformassem os sofistas canonizados dos concílios. A exemplo de seus comparsas do passado, Antônio Conselheiro era um pietista ansiando pelo Reino de Deus, prometido, delongado sempre e ao cabo de todo esquecido pela Igreja ortodoxa do século II $\left(O S\right.$, p.278-279). ${ }^{126}$

126 E não apenas se encontrariam no Conselheiro traços anteriormente verificados em Montano; Euclides considera possível supor no antigo heresiarca aquilo de que tinha certeza em relação ao líder sertanejo: "O frígio pregava-a [a moral, 'a castidade exagerada ao máximo horror pela mulher'], talvez como o cearense, pelos ressaibos remanentes das desditas conjugais" (OS, p.276). Quanto ao "refluxo do cristianismo para o seu berço judaico", por este último se entenda, principalmente a expectativa da instauração do 
Mas esses pontos de contato são acessórios, na análise euclidiana. Mais importantes e decisivas são as concepções de fundo. $O$ beato dos sertões refaz o caminho do frígio:

Esta identidade avulta, mais frisante, quando se comparam com as do passado as concepções absurdas do esmaniado apóstolo sertanejo. Como os montanistas, ele surgia no epílogo da Terra $[\ldots]$ O mesmo milenarismo extravagante, o mesmo pavor do Anticristo despontando na derrocada universal da vida. O fim do mundo próximo... (OS, p.276)

$\mathrm{O}$ ascetismo exigido dos adeptos de um e outro movimento tinha a mesma justificativa: "todas as fortunas estavam a pique da catástrofe iminente e fora temeridade inútil conservá-las" (OS, p.276). Justifica-se que a pregação do Conselheiro seja monotemática: "De todas as páginas de catecismos que soletrara ficara-lhe preceito único: 'Bem aventurados os que sofrem..." (OS, p.300; grifo de Euclides)

Aqui se chega ao ponto fundamental: Euclides vê em Belo Monte as mesmas expectativas de tipo milenarista cultivadas no seio do montanismo. Essa identificação lhe permite mais uma vez recorrer a Renan, agora de forma servil. Se o profetismo de Montano, que, "como todos os profetas da nova aliança, transbordava de maldições contra o século e contra o império romano", não tratava de outra coisa que "o julgamento próximo, a punição dos perseguidores, a destruição do mundo profano, o reino de mil anos e suas delícias" (MA, p.215), a proclamação do Conselheiro não fugiria ao modelo: tinha "o mesmo tom com que despontou na Frígia, avançando para o Ocidente. Anunciava, idêntico, o juízo de Deus, a desgraça dos poderosos, o esmagamento do mundo profano, o reino de mil anos e suas delícias" (OS, p.278). A transcrição reforça a identificação entre um movimento e outro. Com um agravante: a manifestação sertaneja tem séculos de atraso.

O perfil do arraial conselheirista, desenhado por Euclides, é decorrente desta perspectiva. O que ali se vivia era apenas prefiguração do que estava para se dar, do qual apenas eles seriam os beneficiados. Eis o motivo da separação do mundo, da recusa em observar as leis estabelecidas, da revolta contra a República, que segundo tantos a partir de Euclides teria sido a marca do cotidiano do arraial. ${ }^{127}$

reino de Deus neste mundo, como julgava Euclides que Belo Monte estaria aguardando (veja Marilena Chauí. Brasil: mito fundador e sociedade autoritária. Perseu Abramo, São Paulo, 2000, p.78).

127 "O rebelado [o Conselheiro] arremetia com a ordem constituída porque lhe afigura- 
Mas é preciso ser mais explícito. É Os sertões que funda essa vertente interpretativa a respeito de Belo Monte, que tamanha repercussão haveria de ter posteriormente. Como já foi explicado, esse perfil não encontra qualquer apoio nos documentos conhecidos. A inserção da já comentada "profecia" num contexto narrativo que a toma como exemplo da suposta pregação milenarista do Conselheiro, é expressão clara do seu equívoco. ${ }^{128}$ Sua leitura não considerou uma distinção funva iminente o reino de delícias prometido. Prenunciava-o a República-pecado mortal de um povo - heresia suprema indicadora do triunfo efêmero do Anti-Cristo" (OS, p.319). 128 A ignorância a respeito das convicções conselheiristas, mormente as de cunho escatológico, talvez explique por que Euclides acabou por recorrer a Montano. Mas ele não precisava ter ido tão longe. Bastava transcrever em seu livro maior o diálogo esclarecedor travado com um "jaguncinho" de catorze anos, Agostinho, a 19/08/1897, registrado numa das reportagens enviadas a $O$ Estado de São Paulo (DE, p.105-111). Aprisionado e trazido à capital da Bahia, Agostinho é submetido a um interrogatório, de cuja importância Euclides se mostra consciente. Depois de se ter informado sobre a gente do arraial e seus líderes, bem como do cotidiano da vila, as perguntas foram "sobre questões mais sérias": armas e convicções religiosas. Quanto a estas últimas, a surpresa de Euclides se manifesta na resposta à pergunta pela promessa do Conselheiro a quem morresse em combate: "Salvar a alma". Por que a resposta "soou inesperada" a Euclides, se "salvar a alma" era tudo a que o cristão mediano, minimamente conhecedor do catecismo, aspirava? O espanto parece vir justamente da concordância, nos termos, entre as promessas do herege e o que era ensinado conforme o catecismo tridentino, certamente conhecido de Euclides! Pois para o inquisidor, que a essa altura sintetizava o sentimento da nação e perguntava o que na verdade julgava já saber, importava marcar a diferença, arrancar a aberração, comprovar o absurdo. Não podia contar com uma concordância em assunto sobre o qual julgava ter certeza e justificava todos os adjetivos com que os sertanejos eram classificados: aquilo em que acreditavam. O fato de esta parte do interrogatório e as surpresas por ele provocadas não terem sido inseridas em Os sertões, certamente porque não se coadunavam com o modelo de Belo Monte que o autor insiste em alimentar, esclarece, por outro lado, porque foi necessário recorrer a Renan e ao montanismo: para configurar um modelo completamente distinto, em que a diferença fica definitivamente marcada, o atavismo salientado, a aberração estabelecida (veja Marco Antonio Villa. "O 'Diário de uma expedição' e a construção de Os sertões”. In: José Leonardo do Nascimento (org.) Os sertões: releituras e diálogos. Unesp, São Paulo, 2002, p.23). Também nesse aspecto é verdade que Euclides, na confecção de Os sertões, "tem necessidade de interpretar o movimento de Canudos como movimento milenarista" (Edgar Salvador de Decca. "Euclides e Os sertóes: entre a literatura e a história". In: Rinaldo de Fernandes [org.] O clarim e a oração. Geração, São Paulo, 2002, p.164; grifo nosso), já que não é mais possível continuar desenhando-o a partir da Vendéia de Victor Hugo. Se não monarquista, milenarista: sempre o "outro". Assim, não é apenas "ao transformismo sociológico" que "a idéia de conspiração monárquica vai cedendo o passo" (Luiz Costa Lima. O controle do imaginário: razão e imaginação nos tempos modernos. 2 ed., Forense, Rio de Janeiro, 1989, p.210), também à depreciação religiosa radicalizada. Ou, dizendo mel- 
damental entre expectativas milenaristas e aguardo de um juízo final, temerário e iminente; aquelas supõem este, mas nem todo julgamento escatológico é pensado na perspectiva de um milênio vindouro. ${ }^{129}$

No entanto, Euclides não teme tirar as conseqüências de sua "invenção": se na antiga Frígia "uma credulidade desenfreada, uma fé a toda prova nos carismas espirituais, faziam do montanismo um dos tipos de fanatismo mais exagerados da história da humanidade" (MA, p.233), o que se via no sertão baiano não merecia outra classificação. Assim, o recurso a Renan, particularmente a sua exposição sobre o montanismo, ocupa papel significativo na tarefa a que Euclides se propõe: descobrir o sentido daquela manifestação sertaneja sem sentido. É um verdadeiro disparate a presença de "um heresiarca do século II em plena idade moderna" ( $O S$, p.278), liderando um arraial de gente fanática e ignorante.

Constata-se também que a recuperação de manifestações heréticas do princípio do cristianismo tinha a finalidade de mostrar o atraso do que se via nos sertões baianos: "todas as seitas em que se fracionava a religião nascente, com os seus doutores histéricos e exegeses hiperbólicas, forneceriam hoje casos repugnantes de insânia. E foram normais" (OS, p.255). ${ }^{130}$ Antonio Conselheiro e seu séqüito teriam lugar garantido e fariam sentido se houvessem aparecido dezessete, dezoito séculos antes. Mas hoje, como

líder de uma "igreja" à margem da instituição religiosa oficial situada nos parâmetros positivistas de civilização, o Conselheiro é visto como "desnorteado apóstolo" em "missão pervertedora" que "reunia no misticismo doentio todos os erros e su-

hor: o transformismo sociológico se soma de forma importante radicalizar a depreciação da religião do outro. Por outro lado, saliente-se que, se nos termos a escatologia do Conselheiro não diferia substancialmente daquela estabelecida em Trento ("a Igreja católica insistiu doravante muito mais no juízo particular que no Juízo Final": Jean Delumeau. História do medo no Ocidente: 1300-1800: uma cidade sitiada. Companhia das Letras, São Paulo, 1996, p.238), em termos práticos a distância era radical, na medida em que o Conselheiro rompia o monopólio dos padres na administração destas realidades últimas e do acesso a elas.

129 As confusões no tocante a essas duas concepções são comuns, e levam a equívocos quando se pretende compreender o universo religioso dos diversos movimentos religiosos (Jean Delumeau. História do medo no Ocidente..., p.207-215).

130 A percepção do Conselheiro, acompanhado de figuras desconhecidas do cristianismo das origens, mormente Montano da Frígia, fica definitivamente comprometida: ele "está fora do nosso tempo" (OS, p.274). 
perstições que formam o coeficiente de redução de nossa nacionalidade". ${ }^{131}$

Ou seja, Belo Monte e o Conselheiro estão na margem da margem, são o atraso do atraso.

Mas a recuperação do montanismo tem outra razão, além do evidenciar o atavismo do Conselheiro: este se alimentaria de esperanças escatológicas similares àquelas de que viveram as comunidades cristãs da Frígia e de outras regiões nos séculos II e III. No entanto, o que Euclides fez não foi colocar dois movimentos milenaristas em paralelo, mas transformar, arbitrariamente, a pregação de Antonio Conselheiro, por meio de sua associação com a de Montano, numa pregação de cunho milenarista. Foi a exposição de Renan sobre o montanismo que permitiu a Euclides desenhar o pano de fundo quiliasta em que os poucos dados recolhidos em Belo Monte puderam ser inseridos. $\mathrm{O}$ Conselheiro euclidiano tem em Marc-Aurèle a base de sua insânia, na medida em que, atavicamente, atualiza as heresias da Frígia do século II. Essa estigmatização do líder de Belo Monte se insere na longa tradição de caracterizar as expressões religiosas outras como heréticas ${ }^{132}$, e é uma versão atualizada da estigmatização (agora especificamente do Conselheiro) que Euclides propusera nas reportagens, quando definia o outro (os jagunços) como fanático, demonizava-o (lembremo-nos da "legião de demônios") e determinava sua eliminação, exigida pela "mal-

131 Aleilton Fonseca. "Os sertões: as prédicas de Antônio Conselheiro e a poesia de Canudos”. In: O olbo da história. Salvador, 1996. v.2, n.3, p.127 (as citações de Os sertões são da p.283).

132 "Quem não vê o enorme perigo de uma crença como essa?", eis a pergunta que Renan se fazia para expor e justificar a reação da hierarquia eclesiástica ao montanismo que se espalhava ameaçadoramente por toda parte (MA p.212-213). Euclides, a todo momento, ao apresentar Antonio Conselheiro e sua suposta pregação, se pergunta pelo perigo, mas também pela insânia das concepções que faziam a vida e as ilusões da gente de Belo Monte. Para ambos a solução para tais fanatismos era um só: "Se Marco Aurélio [...] tivesse empregado a escola primária e um ensino de Estado racionalista, ele teria prevenido mais eficazmente a sedução do mundo pelo sobrenatural cristão" (MA, p.345346). O comentário é inevitável: "é impossível não pensar aqui no mestre-escola reivindicado para os sertões nordestinos" (Célia Mariana F. F. da Silva e Manoel Roberto F. da Silva. "Alexandre de Abonótico". In: Gazeta do Rio Pardo (Suplemento Euclidiano). São José do Rio Pardo, agosto de 1986). A educação serve para eliminar os atavismos, para estabelecer a uniformidade cultural, e em particular para que se abandonem as crendices religiosas e fantasmagóricas. Mas por que razões Euclides não transcreve em Os sertões o registro, recolhido em sua Caderneta de campo (p.23), que dava conta da existência de escolas em Belo Monte? 
dição tremenda dos profetas". ${ }^{133}$ Evidencia-se, portanto, que a aproximação entre o Conselheiro e Montano, por disparatada que tenha sido, conveio aos propósitos do escritor: ela "é precipitada e distorce os fatos históricos, mas vai ao encontro do resultado que proveio da [sua] teoria da mestiçagem e da coletividade anormal". ${ }^{134}$

\section{Exorcizando um anocoreta}

Euclides da Cunha tem consciência da importância que o perfil de Antonio Conselheiro desenhado em Os sertões joga no conjunto da obra. Em carta ao crítico literário Araripe Júnior, poucos meses depois da publicação de seu livro, ele assim se expressa:

A significação histórica do grande agitador sertanejo que delineei apenas, ajustando-se à escola antropológica, aparece mais nítida, explicada pelas circunstâncias especiais do meio que não tive tempo de conhecer e pelo caráter essencial do indivíduo que não apreendi com segurança, dadas as causas perturbadoras que radicavam a minha observação. ${ }^{135}$

Nas notas para a segunda edição da obra, não é outra coisa que se lê: "a sua figura [de Antonio Conselheiro] de pequeno grande homem se explica precisamente pela circunstância rara de sintetizar, de uma maneira empolgante e sugestiva, todos os erros, todas as crendices e superstições, que são o lastro de nosso temperamento" (OS, p.790).

Essa concentração em Antonio Conselheiro se justifica: era pre-

133 O processo de demolição do outro que identificamos nas reportagens euclidianas não é muito distinto daquele que Laura de Mello e Souza descobre nos tempos coloniais: 1) a outra humanidade, 2) a animalização e 3) a demonização (O diabo e a terra de Santa Cruz: feitiçaria e religiosidade popular no Brasil colonial. 6 ed., Companhia das Letras, São Paulo, 1999, p.56ss).

134 Alexandre Otten. "Só Deus é grande”..., p.57. Assinale-se, por outro lado, e apenas a título de observação, que já Gilberto Freyre censurava em Euclides a "importância exagerada ao problema étnico, parecendo não ter atinado com a extensão e a profundidade da influência da chamada 'economia agrário-feudal' sobre a vida brasileira. Ou seja: despreza o sistema monocultor, latifundiário e escravocrata na análise da nossa patologia social; e exalta a importância do processo biológico - mistura de raças - como fator, ora de valorização, ora de deterioração regional e nacional" (Perfil de Euclides e outros perfis. 2 ed., Record, Rio de Janeiro, 1987, p.32).

135 Carta de 09/03/1903. In: Walnice Nogueira Galvão e Oswaldo Gallotti (org.) Correspondência de Euclides da Cunba..., p.153. 
ciso fazê-lo "monstro", na forma de um "anacoreta sombrio, cabelos crescidos até os ombros, barba inculta e longa; face escaveirada; olhar fulgurante; monstruoso [...] alguma coisa de fantástico ou mal-assombrado para aquelas gentes simples" (OS, p.266-267). Um evangelizador "monstruoso, mas autômato" (OS, p.268).

E por que era preciso? Pensamos que Eduardo Hoornaert tem a resposta: tido como uma identidade absolutamente outra, para Euclides o desaparecimento era inevitável. Essa convicção, aliada à denúncia que o autor pretende com seu livro, conflui na caracterização de Antonio Conselheiro como profeta milenarista e na sua demonização. Assim, mais do que um livro contraditório, foi possível a Os sertões soar

como um exorcismo junto à intelectualidade brasileira. Era preciso sacrificar o Conselheiro no altar da honorabilidade brasileira para que a elite do país pudesse recuperar-se do trauma causado pela memória de uma ação tão covarde do governo do país diante de uma comunidade de pobres sertanejos. ${ }^{136}$

Assim, o livro pretensamente vingador não foi a fundo em seu propósito. Pois entre aqueles que deveriam ser vingados havia alguém que, monstro, não merecia defesa ou vindicação. Demandava ser exorcizado. E isso porque o olhar de Euclides sobre o outro é muito similar ao dos primeiros colonizadores europeus; o que abaixo se diz dos navegantes dos séculos XV-XVI vale, com as devidas ressalvas, para o moderno "desbravador" do sertão:

A atitude de Colombo para com os índios decorre da concepção que tem deles. Podemos distinguir, nesta última, duas componentes, que continuarão presentes até o século seguinte e, praticamente, até nossos dias, em todo o colonizador diante do colonizado $[\ldots]$ Ou ele pensa que os índios $[\ldots]$ são seres completamente humanos com os mesmos direitos que ele, e aí considera-os não somente iguais, mas idênticos e este comportamento desemboca no assimilacionismo, na projeção de seus próprios valores sobre os outros ou então parte da diferença, que é imediatamente traduzida em termos de superioridade e inferioridade (no caso, obviamente, são os índios os inferiores): recusa a

136 Eduardo Hoornaert. Os anjos de Canudos: uma revisão histórica. Vozes, Petrópolis, 1997, p.81-82. 
existência de uma substância humana realmente outra, que possa não ser meramente um estado imperfeito de si mesmo. ${ }^{137}$

Esse trágico olhar alimenta-se de um paradigma teológico que, entre nós, tem vida desde quando os portugueses por aqui aportaram. Euclides certamente estranharia, principalmente no caso das reportagens, ser visto como adepto de uma teologia sobre o Brasil que já beirava quatrocentos anos, com deuses e demônios ocupando lugares muito definidos. Ao expressar, o mais das vezes em categorias provenientes do mundo das ciências de seu tempo, a distinção das funções e ocupações, a percepção do rumo inexorável da história, a concepção paternalista quanto a quem deverá construir o futuro da nação, traduz uma visão teológica de fundo, cuja matriz é a interpretação a respeito do Brasil que se vinha fazendo desde os tempos coloniais e se refazia agora perante "um levante cujo fulcro agregador é a religião, coisa que, francamente, para ele [Euclides] cheirava à pior das superstições". ${ }^{138}$

Por fim, vale lembrar que já faz séculos que o demônio está no sertão. Afinal, garantia-nos frei Vicente do Salvador já em 1627, o diabo, não tendo mais lugar na Europa medieval cristianizada, se instalou por aqui, fazendo com que o nome dessas terras não fosse aquele que mencionava o símbolo da salvação e sim um mais conveniente com sua nova morada. E tendo os portugueses roubado a ele, pela evangelização, as terras do litoral, contentando-se "de as andar arranhando ao longo do mar como caranguejos" 139 , restou-lhe preferencialmente o interior. Coube a Euclides precisar exatamente onde ele se encontrava.

\section{Referência}

AGUIAR, Flávio. "A volta da serpente. Um estudo sobre Os sertões, de Euclides da Cunha”. Impresso, s/d.

BOSI, Alfredo. Literatura e resistência. São Paulo: Companhia das Letras, 2002.

Cadernos de Literatura Brasileira. São Paulo, 2002. n 13/14.

137 Tzvetan Todorov. A conquista da América: a questão do outro. 2 ed., Martins Fontes, São Paulo, 1999, p.50.

138 Walnice Nogueira Galvão. Gatos de outro saco..., p.94.

139 Vicente do Salvador. História do Brasil [1500-1627]. 7 ed., Itatiaia, Belo Horizonte, 1982 , p.59 
CHAUÍ, Marilena. Brasil: mito fundador e sociedade autoritária. São Paulo: Perseu Abramo, 2000.

COHN, Norman. Caos, cosmo e o mundo que virá: a origem das crenças no Apocalipse. São Paulo: Companhia das Letras, 1996.

CROSSAN, John D. O Jesus histórico. A vida de um camponês judeu do Mediterrâneo.

CUNHA, Euclides da. Caderneta de campo. São Paulo: Cultrix / Instituto Nacional do Livro, 1975.

CUNHA, Euclides da. Diário de uma expedição. São Paulo: Companhia das Letras, 2000.

CUNHA, Euclides da. Os Sertões: campanha de Canudos. Org. Leopoldo Bernucci, São Paulo: Ateliê / Imprensa Oficial do Estado, 2001.

DECCA, Edgar Salvador de. "Euclides e Os sertões: entre a literatura e a história”. In: FERNANDES, Rinaldo de (Org.) O clarim e a oração. São Paulo: Geração, 2002, p. 157-188.

DELUMEAU, Jean. História do medo no Ocidente: 1300-1800: uma cidade sitiada. São Paulo: Companhia das Letras, 1996.

DELUMEAU, Jean. Mil anos de felicidade: uma história do paraíso. São Paulo: Companhia das Letras, 1997.

FACIOLI, Valentim A. Euclides da Cunha: a gênese da forma. Tese de doutoramento, Universidade de São Paulo, 1990.

FREYRE, Gilberto. Perfil de Euclides e outros perfis. 2 ed., Rio de Janeiro: Record, 1987.

FONSECA, Aleilton. "Os sertões: as prédicas de Antônio Conselheiro e a poesia de Canudos". In: O olho da história. Salvador, 1996. v.2, n.3, p. 125-140.

GALVÃO, Walnice Nogueira. Gatos de outro saco: ensaios críticos. São Paulo: Brasiliense, 1981. 
GAlvÃO, Walnice Nogueira e GALlOTTI, Oswaldo (Org.) Correspondência de Euclides da Cunha. São Paulo: Edusp, 1997.

HOORNAERT, Eduardo. Os anjos de Canudos: uma revisão histórica. Petrópolis: Vozes, 1997.

LANTERNARI, Vittorio. "Milênio". In: Enciclopédia Einaudi. Imprensa Nacional - Casa da Moeda, 1994, s/1, v.30, p.303-324.

LEVINE, Robert. O sertão prometido: o massacre de Canudos. São Paulo: Edusp, 1995.

LIMA, Luiz Costa. O controle do imaginário: razão e imaginação nos tempos modernos. 2 ed., Rio de Janeiro: Forense, 1989.

MONIZ, Edmundo. Canudos: a guerra social. 2 ed., Rio de Janeiro: Elo, 1987.

MYERS, Ched. O evangelho de são Marcos. São Paulo: Paulus, 1992.

NASCIMENTO, José Leonardo do; FACIOLI, Valentim (Org.) Juízos críticos: Os sertões e os olhares de sua época. São Paulo: Nankim / Unesp, 2003.

NOGUEIRA, Ataliba. António Conselheiro e Canudos: revisão histórica. 3 ed., São Paulo: Atlas, 1997.

OTTEN, Alexandre. "Só Deus é grande": a mensagem religiosa de Antonio Conselheiro. São Paulo: Loyola, 1990.

RENAN, Ernst. Marc-Aurèle et la fin du monde antique. CalmannLévy, Paris, 1929.

SALVADOR, Vicente do. História do Brasil [1500-1627]. 7 ed., Belo Horizonte: Itatiaia, 1982.

SEVCENKO, Nicolau. Literatura como missão. Tensões sociais e criação cultural na Primeira República. 4 ed., São Paulo: Brasiliense, 1999. SILVA, Célia Mariana F. F. da; SILVA, Manoel Roberto F. da. "Alexandre 
de Abonótico". In: Gazeta do Rio Pardo (Suplemento Euclidiano). São José do Rio Pardo, agosto de 1986.

SOUZA, Laura de Mello e. O diabo e a terra de Santa Cruz: feitiçaria e religiosidade popular no Brasil colonial. 6 ed., São Paulo: Companhia das Letras, 1999.

THOMPSON, Edward P. A formação da classe operária inglesa. 3 ed., Rio de Janeiro: Paz e Terra, 1997, v. 1.

TODOROV, Tzvetan. A conquista da América: a questão do outro. 2 ed., São Paulo: Martins Fontes, 1999.

VASCONCELLOS, Pedro Lima. "A vitória da vida: milênio e reinado em Apocalipse 20,1-10". In: Revista de Interpretação Bíblica LatinoAmericana. Petrópolis, 1999. n. 34, p. 79-92.

VASCONCELLOS, Pedro Lima. Terra das promessas, Jerusalém maldita: memórias bíblicas sobre Belo Monte (Canudos). Tese de Doutorado, Pontifícia Universidade Católica de São Paulo, 2004.

VILLA, Marco Antonio. "O 'Diário de uma expedição' e a construção de Os sertões". In: NASCIMENTO, José Leonardo do (Org.) Os sertões: releituras e diálogos. São Paulo: Unesp, 2002, p. 11-39.

ZILLY, Berthold. "A guerra como painel e espetáculo. A história encenada em Os sertões”. In: História, Ciências, Saúde. Rio de Janeiro, 1998. v.5 (suplemento), p. 13-37. 